ENCYCIOPEDDE Encyclopédie berbère

BERBERE

$35 \mid 2013$

35| Oasitae - Ortaïas

\title{
Oebillae ou obilae
}

Jehan Desanges

\section{(2) OpenEdition}

Journals

Édition électronique

URL : https://journals.openedition.org/encyclopedieberbere/2798

DOI : 10.4000/encyclopedieberbere.2798

ISSN : 2262-7197

\section{Éditeur}

Peeters Publishers

\section{Édition imprimée}

Date de publication : 1 juin 2013

Pagination : $5708-5709$

ISBN : 978-2-7584-0184-1

ISSN : 1015-7344

\section{Référence électronique}

Jehan Desanges, "Oebillae ou obilae », Encyclopédie berbère [En ligne], 35 | 2013, document 006, mis en ligne le 12 mars 2021, consulté le 17 février 2022. URL : http://journals.openedition.org/ encyclopedieberbere/2798; DOI : https://doi.org/10.4000/encyclopedieberbere.2798

Ce document a été généré automatiquement le 17 février 2022.

(c) Tous droits réservés 


\title{
Oebillae ou obilae
}

\author{
Jehan Desanges
}

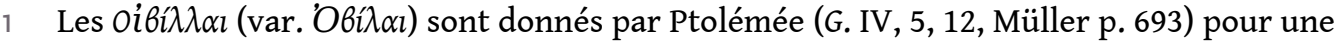
tribu de Marmarique, établie apparemment dans le sud-est de ce nome et mentionnée entre les Sentites* et les Aezari*. Comme, d'après le même Ptolémée (IV, 5, 2-3, p. 677), la Marmarique s'étend vers l'est le long de la mer jusqu'à la Grande Descente (Katabathmos Megas), c'est-à-dire le fond du Golfe de Soloum, on serait porté à situer les Oebillae un peu à l'ouest du méridien de Soloum. Mais il y a souvent chez le géographe alexandrin un fort décalage en longitude entre les sites du littoral et ceux de l'intérieur des terres. Faut-il mettre en rapport avec le nom des Oebillae la ville de Billa (var. Billia) dont Ptolémée (IV, 5, 13, p. 696) fait état à la fin d'une liste de villages de l'intérieur de la Marmarique et qu'il faudrait précisément situer, d'après les coordonnées qu'il lui assigne, au sud-est de ce nome et sur le méridien de la Grande Descente, mais à $5^{\circ} 35^{\prime}$ plus au sud?

INDEX

Mots-clés : Antiquité, Egypte, Libye, Tribu 